\section{An excess of doctors...}

\author{
David Dickson reports from Washington on the levels of \\ manpower in medicine, and womanpower in science
}

AFTER fifteen years' rapid expansion, US medical schools are beginning to produce more doctors than the country needs. Earlier this month the Department of Health, Education and Welfare (DHEW) predicted that the surplus could be between 4,000 and 40,000 by 1990 ; and other estimates make it considerably higher.

Numbers alone, however, hide the fact that not all medical graduates go where they are required. In particular, the more lucrative fields of surgery continue to exert higher attraction than primary health care, especially on those who may leave medical school with outstanding loans of $\$ 40,000$ to $\$ 50,000$.

Ironically the current situation is largely the result of the success of the government's previous efforts to fit medical education to social needs. These were initiated in the late $1960 \mathrm{~s}$, when a national shortage of doctors led the government to offer generous grants to medical schools willing to increase their enrollments.

With the encouragement of 'capitation' grants (based on the number of students) and funds for the creation of new medical schools, the number of places for medical students has doubled, from about 8,000 to 16,000 . And although the rate of expansion has slackened off, there is no indication that it is likely to fall, particularly given the continued excess of applicants over available places.

The consequence of a growing domestic supply plus the influx of foreign doctors during the period of shortage is that, according to figures prepared by DHEW's Bureau of Health Manpower, there will be 600,000 doctors in the US by 1990 - but the need will only be for between 553,000 and 596,000 .

Congress' Office of Technology Assessment (OTA) predicts an even wider gap. In a report on the bureau's statistical methodology published last week, it agrees with the supply figure but points out that the projected need is based on a linear extrapolation of an observed increase in the per capita demand for physicians over the period 1968 to 1976 .

The OTA report also points out, however, that since 1971 the per capita demand has been falling. And that if this trend is combined with expected demographic changes, the need for doctors by 1990 could be as low as 415,000 .

No-one is particularly worried about the surplus itself. Despite the growing signs of a shift away from surgery into general practice, there are still likely to reamin - as $0028-0836 / 80 / 18002-02501.00$ both the DHEW and the OTA report emphasise - fields in need of more doctors, for example, for work among imigrant and minority populations.

The dilemma is over the appropriate response of both the federal government and the medical schools. The Carter Administration is using the over-supply direct federal aid to medical schools should now be dropped, confining assistance to student grants and loans.

The schools, in contrast, feel that relying on tuition fees alone would place unacceptable pressures on students. And that some form of additional support, not tied to providing health services or to funding research which are both tightly regulated, would now be welcome.

So far the administration's attempt to eliminate capitation grants has met limited success. Although omitted from DHEW's budget request for 1980 last year, they were put back by Congress reacting to pressure from the medical schools. In January the President asked that the capitation grants be withdrawn from the 1980 budget, but again Congress disagreed. A further attempt to cut the money out was made in the President's revised budget request last month among the revisions for 1980 . And the issue remains unresolved. figures to support its proposal that all
A political struggle appears to be looming on the Washington horizon over the steps that the US government should take to encourage the participation of women in science.

In passing the National Science Foundation's budget for 1981 last Thursday, the Senate Subcommittee on Health and Scientific Research included a provision for $\$ 23$ million to be allocated to a new 'women in science' programme within the foundation.

The elements of the programme are broadly similar to those included in a bill introduced last year by Senator Edward Kennedy. They include a new centre for women in science, a special committee within the foundation to examine the position of women scientists, the creation of appropriate university positions, and the appointment of a special assistant to the NSF director.

Subcommittee members say the need for the number of women in science remains such a programme is shown by the fact that
However congressional attitudes are changing, reflecting the schools' acceptance of the current illogic of measures to increase doctor supply. Last week a House subcommittee proposed that, in renewing the health education support legislation which runs out this year, capitation grants should be 'phaseddown' by steps of $25 \%$ over the next three years. And although remaining agnostic over whether the nation faces an oversupply of doctors, the subcommittee agreed that no new medical schools should receive federal funding.

The main problem facing the schools is the implication of the growth in tuition fees, which can now go as high as $\$ 8,000$ a year. One approach has been to seek new forms of outside assistance; thirteen private medical schools announced last week that they are to divide $\$ 1.3$ million next year awarded by the Henry J. Kaiser Foundation to assist students with more forthcoming later to those able to raise matching grant from alumni or elsewhere.

Others are seeking new forms of federal support for teaching. "One way would be to develop a two-part system. All schools would get a certain base amount, and you could then pick and choose programmes which might qualify for additional funding"' says Dr Richard Ross, Dean of the Medical Faculty and Johns Hopkins Medical School.

Without some such support, fears are growing that many of the trends which federal funding has encouraged - such as the growing recruitment of students from minority or low-income groups - could be reversed. And that current mismatches between the supply of physicians and health needs may only be exacerbated.

\title{
... and a dearth of women
}

disproportionately low. But to make room for the programme while remaining under the revised ceiling for the NSF's budget proposed by President Carter earlier this month, the committee is recommending a pro rata $9 \%$ cut on all items listed in the original January budget request.

Although the impact on basic research programmes would be mitigated by the transfer of money that would have been spent on upgrading research facilities, this would cut back their increase from $11 \%$ to $7 \%$. Funds for mathematical and physical sciences, for example, would fall from a proposed $\$ 260$ million to $\$ 244$ million.

The corresponding House Subcommittee, in voting on the NSF budget last week, kept closer to the administration's revised request for $\$ 1,074$ million. However, it added applied research and science education items, and cut back the proposed government /industry ocean margin drilling project from $\$ 5$ million to a $\$ 500,000$ study by the National Academy of Sciences. 